\title{
Effect of Spacing on Growth and Increment of Hardwickia binata Roxb. in Semi Arid Region of Rajasthan
}

\author{
M. B. Noor mohamed*, Keerthika A., Dipak Kumar Gupta, Kamla K. Chaudhary, A. K. Shukla and B. L. Jangid
}

ICAR-Central Arid Zone Research Institute (CAZRI), Regional Research Station, Pali-Marwar, Rajasthan (306 401), India

\section{Corresponding Author}

M. B. Noor mohamed

e-mail: mohamedforester@gmail.com

\author{
Article History \\ Article ID: IJEP0259 \\ Received in $21^{\text {st }}$ June, 2018 \\ Received in revised form $22^{\text {nd }}$ July, 2018 \\ Accepted in final form $17^{\text {th }}$ August, 2018
}

\begin{abstract}
Spacing is one of the most important considerations in plantations to avoid the competition and effective utilization of resources among the agricultural crops and trees. The present experiment was conducted to determine the effect of spacing on growth and increment of 30year old Hardwickia binata Roxb. at Central Arid Zone Research Institute (CAZRI), Regional Research Station, Pali-Marwar which is located between $25^{\circ} 47^{\prime}-25^{\circ} 49^{\prime} \mathrm{E}$ and $73^{\circ} 17^{\prime}-73^{\circ} 18^{\prime} \mathrm{N}$ at $217-220 \mathrm{~m} \mathrm{MSL}$. Two tree spacing i.e. closer spacing (666 tree ha- ${ }^{-1}$ with $5 \times 3 \mathrm{~m}^{2} \mathrm{spacing}$ ) and wider spacing ( 333 tree ha-1 with $10 \times 3 \mathrm{~m}^{2}$ spacing) were adopted with Randomized Block Design and replicated twice. Results exhibited significant effect of spacing on the growth and yield of the trees in Hardwickia binata plantation. Among the different spacing regimes, wider spacing of $3 \times 10 \mathrm{~m}^{2}$ resulted better tree height, $\mathrm{DBH}$, tree circumferences, number of branches, clear bole height, crown width, crown length and tree volume. In general, DBH, tree circumference, crown width and crown length and tree volume is more in wider spacing with less tree density while lesser in closer spacing with high tree density. But there is not much differences in tree height and number of branches between two different spacing. Therefore, this study indicates that the increased spacing between the Hardwickia binata trees resulted better growth and increment compared to closer spacing.
\end{abstract}

Keywords: Spacing, Growth and Increment, Hardwickia binata, Semi-arid region

\section{Introduction}

Hardwickia binata Roxb. is a multipurpose tree species (MPTs) which belongs to the family leguminosae, subfamily caesalpinoidae and considered to be a good nitrogen fixing fodder yielding tree in semi-arid conditions of India. The tree yields extremely hard, very heavy and durable timber apart from high quality fuel-wood (Roy, 1996) and rich fodder in terms of crude protein (Singh, 1982). This tree species is suitable for agroforestry farming because of its fast growth, less canopy development and nitrogen fixation. It is amenable to pruning practices. It coppices and pollards well. The use of Hardwickia binata as a main tree component in silvipasture (Hazra, 1995) and in agrosilviculture (Khadse and Bharad, 1996a) has been studied extensively.

Tree stand density is a very important tool of silvicultural treatment and offer a means to affect the growing conditions of trees and thus, also the stem wood production. But due to the limited resources in arid and semi-arid regions, benefits from short rotation plantations largely depends on the judicious management of soil and water resources (Bhuvneshnagar et al., 2015). Spacing trials have traditionally been carried out to come up with practical spacing for commercial tree crops to reduce intra-specific competition, optimize growth and get quick returns (Kirongo et al., 2012). It has designed to create growing environments that mimic resource capture (especially light) and/or available moisture and nutrients (Nambiar and Sands, 1993). Even with good rainfall and crop husbandry (weeding, climber cutting, fertilization), individual trees will still need sufficient growing space to ensure optimum growth (Auld et al., 1987; Evans, 1982). And also, trees with ample growing space show much stronger growth and can better withstand pests and diseases and thus mature earlier and hence reducing investment risk (Evans, 1982; Auld et al., 1987, Balneaves and Clinton, 1992). In addition to that tree spacing influences individual tree growth and in turn wood properties and tree morphology (Francosis et al., 2016).

Therefore, to study the effect of spacing on growth and increment of Hardwickia binata has become necessary to be considered and determined. Under these circumstances, the study has been conducted to find the effect of spacing and plant density on growth of Hardwickia binata trees under silvipastoral system in semi-arid condition of Rajasthan.

\section{Materials and Methods}

This study was conducted at Central Arid Zone Research 
Institute (CAZRI), Regional Research Station, Pali-Marwar which is located between $25^{\circ} 47^{\prime}-25^{\circ} 49^{\prime} \mathrm{E}$ and $73^{\circ} 17^{\prime}-73^{\circ} 18^{\prime}$ $\mathrm{N}$ at 217-220 $\mathrm{m}$ above mean sea level and receives 460 $\mathrm{mm}$ annual average rainfall with annual maximum mean temperature $42{ }^{\circ} \mathrm{C}$ and minimum $7{ }^{\circ} \mathrm{C}$. The soil is shallow in depth $(30-45 \mathrm{~cm})$ with sandy clay loam to sandy loam texture, 1.35-1.5 $\mathrm{Mg} \mathrm{m}^{-3}$ bulk density, 7.7-8.4 pH, 0.15-0.55 $\mathrm{dSm}^{-1}$ electrical conductivity and a dense underlying layer of murrum (highly calcareous weathered granite fragment coated with lime).

The experimental site was planted by Hardwickia binata Roxb. intercropped with Cenchrus setigerus silvi-pasture systems with two tree spacing i.e. closer spacing (666 tree ha ${ }^{-1}$ with $3 \times 5 \mathrm{~m}^{2}$ spacing) and wider spacing (333 tree ha-1 with $3 \times 10$ $\mathrm{m}^{2}$ spacing) were established at the station in the year 1986. Randomized Block design was adopted for planting and replicated twice. The data regarding tree height, $\mathrm{DBH}$, tree circumferences, number of branches, clear bole height, crown width, crown length and tree volume were recorded in the month of March during the year 2017.

\section{Results and Discussion}

The wider spacing $\left(3 \times 10 \mathrm{~m}^{2}\right)$ resulted in the higher tree height $(9.625 \mathrm{~m})$, while the narrow spacing $\left(3 \times 5 \mathrm{~m}^{2}\right)$ recorded the lower tree height $(8.523 \mathrm{~m})$. Minimum and maximum height of the tree in the stand was $7.0 \mathrm{~m}$ and $11.0 \mathrm{~m}$ at closer spacing and $9.0 \mathrm{~m}$ and $10.5 \mathrm{~m}$ at wider spacing (Table 1). There is not much differences between different spacing in tree height (Figure 1). It shows that tree densities did not affect the rate of increase in height of the trees. These results are in line with the findings of Mohsin et al., 1996; Bisaria et al., 1999. $\mathrm{DBH}$ and tree circumference was relatively higher at the wider spacing and lower at the closer spacing during the period of study. Maximum DBH was recorded in trees planted at wider spacing $(24.40 \mathrm{~cm})$ while minimum at closer spacing (18.13 $\mathrm{cm}$ ) (Table 1). Maximum tree circumference was registered in trees having a lower density $(76.66 \mathrm{~cm})$ followed higher

\begin{tabular}{|c|c|c|c|}
\hline $\begin{array}{l}\text { SI. } \\
\text { No. }\end{array}$ & Particulars & $\begin{array}{l}\text { Closer spac- } \\
\text { ing }\left(3 \times 5 \mathrm{~m}^{2}\right)\end{array}$ & $\begin{array}{l}\text { Wider spac- } \\
\text { ing }\left(3 \times 10 \mathrm{~m}^{2}\right)\end{array}$ \\
\hline 1. & Tree height (m) & 8.523 & 9.625 \\
\hline 2. & $\mathrm{DBH}(\mathrm{cm})$ & 18.13 & 24.40 \\
\hline 3. & $\begin{array}{l}\text { Tree circumference } \\
(\mathrm{cm})\end{array}$ & 56.95 & 76.66 \\
\hline 4. & No. of branches & 2.750 & 2.888 \\
\hline 5. & Crown width (m) & 5.900 & 6.902 \\
\hline 6. & Crown length (m) & 5.923 & 7.191 \\
\hline 7. & Clear bole height $(\mathrm{m})$ & 2.574 & 2.433 \\
\hline 8. & Tree volume $\left(\mathrm{m}^{3}\right.$ tree $\left.^{-1}\right)$ & 0.223 & 0.460 \\
\hline
\end{tabular}

density plantation $(56.95 \mathrm{~cm})$. The study indicates that if the spacing between tree rows is wider, more trees fall in bigger diameter classes over a period of time (Figure 1). It showed that there was less competition amongst Hardwickia binata trees under wider spacing while in closer spacing competition

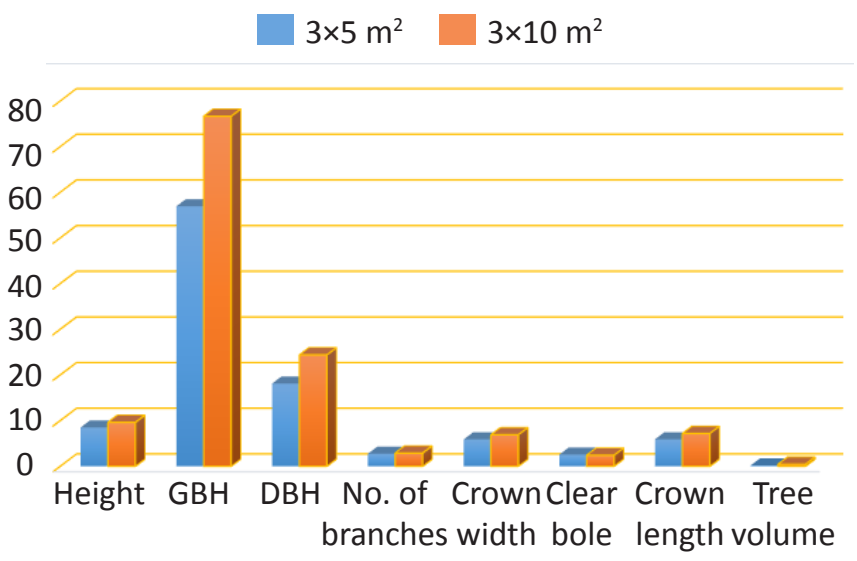

Figure 1: Growth parameter of Hardwickia binata at different spacing

is taken place among the trees, resulting in lesser diameter growth. The stems were relatively bigger at the widest spacing, presumably because of the higher availability of soil, moisture and light resources (Songyos et al., 2013). These results are supported with the findings of Sheikh (1988); Chaturvedi (1992); Hafeez and Hafeezullah (1993), Misra et al. (1996), Bisaria et al. (1999); Nissen et al. (2001). Spacing did not affect number of branches in Hardwickia binata plantation. However, the narrow spacing of $3 \times 5 \mathrm{~m}^{2}$ showed the lower number of branches (2.750) and wider spacing $3 \times 10 \mathrm{~m}^{2}$ showed the higher number of branches (2.888) (Table 1). The clear bole contribution is more in closer spacing as compared to wider spacing. Maximum clear bole height recorded was $2.574 \mathrm{~m}$ in closer spacing $\left(3 \times 5 \mathrm{~m}^{2}\right)$ while minimum was $2.433 \mathrm{~m}$ in wider spacing. It revealed that higher the tree density will lead to clearer bole than the lower density due to competition among trees results increasing the self-pruning ability.

Crown width and Crown length was maximum (6.902 $\mathrm{m}$ and $7.191 \mathrm{~m})$ in wider spacing $\left(3 \times 10 \mathrm{~m}^{2}\right)$ and minimum $(5.900 \mathrm{~m}$ and $\left.5.923 \mathrm{~m}^{2}\right)$ was observed in closer spacing $\left(3 \times 5 \mathrm{~m}^{2}\right)$ (Table $2)$. Crown width and crown length was better in wider spacing as compared to closer spacing. It indicated that spacing is very important factor for crown development in Hardwickia binata plantation. According to Samsuzzamam et al. (2002) proper tree crop spacing and pruning management helps to reduce

Table 2: Height and diameter classes of Hardwickia binata at different spacing

\begin{tabular}{llcc}
\hline SI. & Class & $\begin{array}{c}\text { Closer spac- } \\
\text { ing }\left(3 \times 5 \mathrm{~m}^{2}\right)\end{array}$ & $\begin{array}{c}\text { Wider spacing } \\
\left(3 \times 10 \mathrm{~m}^{2}\right)\end{array}$ \\
No. & & $7.0-11.0$ & $9.0-10.5$ \\
1. & Height class $(\mathrm{m})$ & $12.98-24.51$ & $18.14-29.92$ \\
\hline
\end{tabular}


negative tree crop interaction and thereby greatly influence the component productivity. It indicated that there is more crown expansion in trees having wider spacing and lesser crown expansion in trees having closer spacing. Britt and Reynolds, 2011 also reported that the lower crown spread in closer spacing might be due to reduced availability of light as a result of increased competition from neighboring treesThe tree volume was highest $\left(0.460 \mathrm{~m}^{3}\right.$ tree $\left.^{-1}\right)$ at the spacing of $3 \times 10 \mathrm{~m}^{2}$ and the lowest volume was in closer spacing of $3 \times 5$ $\mathrm{m}^{2}\left(0.223 \mathrm{~m}^{3}\right.$ tree $\left.^{-1}\right)$. These results are in agreement with findings of Singh et al., 1983. This may be ascribed to better utilization of moisture, fertilizers and nutrients beyond the reach of arable crops with additional benefit of wider spacing and of cultural operations. Reducing spacing between trees will therefore exacerbate the negative effects. Sands and Nambiar (1984) and Nambiar and Sands (1993) reported serious growth losses resulting from intense competition for water and nutrients arising from competition effects.

There was not much differences in $\mathrm{pH}$ and $\mathrm{EC}$ in soil of two different spacings under Hardwickia binata plantation. However, the $\mathrm{pH}$ and $\mathrm{EC}$ registered as higher in wider spacing while lower in high density with closer spacing. But there was much difference in organic carbon content between two different spacing under Hardwickia binata plantation. The organic carbon content was recorded more in closer spacing $(0.54 \%)$ compared to wider spacing $(0.51 \%)$. This may due to higher leaf litter content in closer spacing $\left(3 \times 5 \mathrm{~m}^{2}\right)$ compared to wider spacing (Table 3).

Table 3: Effect of different spacing and tree density on soil properties under Hardwickia binata plantation

\begin{tabular}{llcc}
\hline SI. & Properties & $\begin{array}{c}\text { Closer spac- } \\
\text { No. }\end{array}$ & $\begin{array}{c}\text { Wider spacing } \\
\left(3 \times 5 \mathrm{~m}^{2}\right)\end{array}$ \\
\hline 1. & $\mathrm{pH}$ & 8.1 & 8.3 \\
2. & $\mathrm{EC}\left(\mathrm{ds} \mathrm{\textrm {m } ^ { - 1 } )}\right.$ & 0.34 & 0.42 \\
3. & Soil organic carbon $(\%)$ & 0.54 & 0.51 \\
\hline
\end{tabular}

\section{Conclusion}

There was an effect present on the growth and increment of the trees in Hardwickia binata plantation with different spacing. Tree circumference, crown width, crown length and tree volume were more in wider spacing. Closer spacing exhibited high clear bole length due to self-pruning ability of trees because of more competition. Therefore, this study resulted that the increased spacing between the Hardwickia binata trees will leads to better growth and increment compared to closer spacing.

\section{Acknowledgement}

We express our gratitude to The Director, CAZRI, Jodhpur, Scientists, technical officers, field workers of CAZRI-RRS, Pali for their cooperation, support and assistance in field during the study.

\section{References}

Auld, B.A., Menz, K.M., Tisdel, C.A., 1987. Weed Economics, Academic Press.

Balneaves, J.M., Clinton, P., 1992. Weed control increases radiate pine productivity. What's New in Forest Research, No. 220. NZ FRI, Rotorua.

Bisaria, A.K., Solanki, K.R., Newaj, A.R., Tiwari, R., 1999. Effect of tree densities and environmental factors on Hardwickia binata and companion crops in agrisilviculture. J. Trop. For. 15, 93-102.

Britt, J.R., Reynolds, J.P., 2011. Volume and crown characteristics of juvenile loblolly pine grown at various ratios of between and within row spacing. http://www. afoa.org/ PDF/CI 1010e.pdf.

Chaturvedi, A.N., 1992. Optimum rotation of harvest for poplars in farmlands under agroforestry. The Indian Forester 118(2), 81-88.

Evans, J., 1982. Plantation forestry in the tropics, Second Edition. Clarendon Press Oxford, 268.

Francois, H., Cornelia, K., Pierre-Yves, P., Alexis, A., Guy, P., Jean, M., 2016. Effect of Tree spacing on tree level volume growth, morphology, and wood properties in a 25-Year-old Pinus banksiana plantation in the boreal forest of Quebec. Forests 7, 276.

Hafeez, S.M., Hafeezullah, M., 1993. Suitable spacing for planting of poplar in agroforestry systems. Pakistan Journal 43(4), 197-203.

Hazra, C.R., 1995. Effect of tree species on fodder and seed yields of berseem, soil properties and residual effect of dinanath grass. Range Management and Agroforestry 16(1), 73-78.

Khadse, V.A., Bharad, G.M., 1996. Performance of annual crops under canopy of $H$. binata Roxb. (Anjan) in agroforestry system. Journal of Soils and Crops. 6(2), 151-153.

Kirongo, B., Mbelase, A., Kingiri, S., Joseph, H., Lazare, E., 2012. Spacing and genotype on height and diameter growth of four Eucalyptus under short rotation. Journal of Tropical Forest Management (Manajemen Hutan Tropika). XVIII (1), 1-9.

Misra, K.K., Rai, P.N., Jaiswal, H.R., 1996. Effect of spacing and plant density on the growth of poplar (Populus deltoides Bartr.Ex Marsh). The Indian Forester 122(1), 65-68.

Mohsin, F., Singh, R.P., Singh, K., 1996a. Growth and biomass production by Populus deltoids under agroforestry in Tarai of Kumaun region, U.P. The Indian Forester 122(7), 631-636.

Nagar, B., Rawat, S., Rathiesh, P., Sekar, I., 2015. Impact of initial spacing on growth and yield of Eucalyptus camaldulensis in arid region of India. World Applied Sciences Journal 33(8), 1362-1368.

Nambiar, E.K., Sands, R., 1993. Competition for water and nutrients in forests. Canadian Journal of Forest 
Research 23, 1955-1968.

Nissen, T.M., Midmore, D.J., Keeler, A.G., 2001. Biophysical and economic tradeoffs of intercropping timber with food crops in the Philippine uplands. Agricultural systems 67, 49-69.

Roy, M.M., 1996. Hardwickia binata for silvipastoral systems in India. Agroforestry Today 8, 12-13.

Samsuzzaman, S., Ali, M.A., Momin, M.A., Kakim, M.R., Uddin, M.M., 2002. Tree-crop interactions as affected by tree spacing and pruning management in Bangladesh. The Indian Forester 128(11), 1231-1244.

Sands, R., Nambiar, E.K., 1984. Water relations of Pinus radiata in competition with weeds. Canadian Journal of Forest Research 14, 233-237.
Sheikh, M.I., 1988. Management of hybrid poplar for optimum yield of wood. Pakistan Journal 38 (3), 157165.

Singh, R.V., 1982. Fodder trees of India. Oxford and IBH Publications Co., New Delhi, Bombay, Calcutta-663.

Singh, S.P., Sharma, R.S., Jain, R.C., 1983. Effect of spacing and thinning in Casuarina stands. Indian Forester 109, 12-16.

Songyos, C., Kunn, K., Sayan, T., Prapa, S., 2013. Effect of spacing on growth, biomass yield and quality of Leucaena (Leucaena leucocephala (Lam.) de Wit.) for renewable energy in Thailand. Journal of sustainable bioenergy systems 3, 48-56. 